\title{
Uji Masa Simpan Pelet Trichoderma harzianum dan Kemampuannya dalam Menghambat Perkembangan Penyakit Layu Fusarium pada Bibit Tomat
}

\author{
(Storing Period of Trichoderma harzianum Pellets and its ability to Inhibit the development of \\ Fusarium Wilt Disease on Tomato Seeds)
}

\author{
Rizka Musfirah $^{1}$, Rina Sriwati ${ }^{2}$ dan Tjut Chamzurni ${ }^{2 *}$ \\ ${ }^{1}$ Program Studi Agroteknologi, Fakultas Pertanian, Universitas Syiah Kuala \\ ${ }^{2 *}$ Program Studi Proteksi Tanaman, Fakultas Pertanian, Universitas Syiah Kuala
}

\begin{abstract}
Abstrak. Tomat (Solanum lycopersicum) merupakan salah satu komoditas pertanian yang ditanam secara luas di seluruh dunia, termasuk di Indonesia, karena memiliki rasa yang khas dan enak, juga memiliki nilai gizi seperti sumber vitamin A dan $\mathrm{C}$ yang sangat baik. Produksi tomat mengalami penurunan setiap tahun, salah satunya diakibatkan oleh organisme penganggu tanaman (OPT) yaitu patogen Fusarium oxysporum sehingga perlu dilakukan pengendalian hayati yaitu menggunakan Trichoderma harzianum dalam bentuk formulasi pelet yang praktis, efektif, dan efesien. Penelitian ini menggunakan Rancangan Acak Lengkap (RAL) non faktorial yang terdiri dari 6 perlakuan dengan 3 ulangan, setiap perlakuan terdiri dari 10 unit bibit tomat. Penelitian ini terdiri dari 6 perlakuan yaitu perlakuan A (masa simpan pelet $T$. harzianum 4 minggu), B (masa simpan pelet $T$. harzianum 3 minggu), C (masa simpan pelet T. harzianum 2 minggu), D (masa simpan pelet T. harzianum 1 minggu), E (masa simpan pelet $T$. harzianum 0 minggu), F (tanpa perlakuan pelet $T$. harzianum). Peubah yang diamati yaitu pre-emergence damping off, post-emergence damping off, masa inkubasi, persentase tanaman layu, tinggi tanaman, dan jumlah daun. Hasil penelitian menunjukkan bahwa pelet $T$. harzianum yang disimpan 4 minggu efektif dalam menghambat perkembangan penyakit layu fusarium seperti menunda masa inkubasi sampai 7 HSI, menekan pre-emergence damping off sampai 90\%, post-emergence damping off 92,95\%, serta mampu meningkatkan tinggi tanaman sampai $19,63 \mathrm{~cm}$ dan meningkatkan jumlah daun rata-rata 7 helai pada 35 HSI.
\end{abstract}

Kata kunci: Pengendalian hayati, Trichoderma harzianum, Fusarium oxysporum, dan Tomat.

\begin{abstract}
Tomato (Solanum lycopersicum) is one of the most widely grown commodities in the world, including Indonesia. It has a distinctively good taste and many nutritional value such as vitamin A and C. However, tomato production has decreased every year. One of the main cause is the attacks by pathogens, named Fusarium oxysporum. A Biological control is necessary and the use of Trichoderma harzianum in the form of pellets is recommended because of its effectiveness, efficiency and practical use. This research used a Completely Randomized Design (RAL) non-factorial consisted of 6 treatments with 3 replications, each treatment consisted of 10 units of tomato seedlings. The 6 treatments are named as treatment A (T. harzianum pellet saving 4 weeks), B (T. harzianum pellet saving period 3 weeks), C (shelf life of 2 weeks $T$. harzianum pellet), D (shelf life of pellet $T$ harzianum 1 week), E (shelf life of pellet $T$. harzianum 0 weeks), and F (without $T$. harzianum pellet treatment). The variables observed in this study are pre-emergence damping off, post-emergence damping off, incubation period, the percentage of wilted plants, plant height, and the number of leaves. The results showed that pellets of $T$. harzianum stored 4 weeks effectively inhibiting the development of fusarium wilt disease such as delaying incubation period up to 7 HSI (Days After Incubation), suppressing the pre-emergence damping off up to $90 \%$ and post-emergence damping off to $92.95 \%$, also able to increase the plant height up to $19.63 \mathrm{~cm}$ and increase the average leaf number of 7 strands at 35 HSI.
\end{abstract}

Keywords : Biological control, Trichoderma harzianum, Fusarium oxysporum, and Tomato.

\section{PENDAHULUAN}

Tomat (Solanum lycopersicum) merupakan salah satu komoditas pertanian yang ditanam secara luas di seluruh dunia, termasuk di Indonesia dan semakin populer keberadaannya sejak abad terakhir. Selain memiliki rasa yang khas dan enak, buah tomat juga memiliki nilai gizi seperti sumber vitamin A dan $\mathrm{C}$ yang sangat baik. Selain dikonsumsi sebagai tomat segar dan bumbu masakan, tomat juga dapat diolah sebagai bahan baku industri makanan seperti saus tomat dan sari buah (Wasonowati, 2011). Buah tomat merupakan salah satu sayuran yang bernilai ekonomi tinggi dan masih memerlukan penanganan serius dalam 
hal kuantitas dan kualitas buahnya (Hanindita, 2008). Produksi tomat pada tahun 2015 di provinsi Aceh mengalami penurunan dibandingkan pada tahun 2014 yaitu sebesar 29,77\%. Pada tahun 2014, tanaman tomat mampu berproduksi 30.035 ton dan mengalami penurunan pada tahun 2015 menjadi 21.092 ton (BPS, 2015).

Salah satu penyebab turunnya produksi tomat disebabkan oleh serangan organisme pengganggu tanaman (OPT) yaitu penyakit layu Fusarium. Cendawan ini merupakan patogen tular tanah yang mampu bertahan dalam jangka waktu lama dalam bentuk klamidospora meskipun tidak terdapat tanaman inang.

Dewasa ini, pengendalian OPT khususnya penyakit tanaman banyak menggunakan bahan kimia sintetis. Soesanto (2008) menyatakan, bahwa penggunaan kimia sintetis berdampak buruk dibandingkan agensia pengendali hayati terhadap manusia. Produk pertanian tidak menyimpan residu agensia pengendali hayati di dalamnya, sehingga aman dikonsumsi oleh manusia (Sharma et al., 2011).

Pengendalian hayati memiliki sifat ramah lingkungan dan berkelanjutan. Agensia hayati telah banyak digunakan untuk mengendalikan berbagai jamur patogen. Salah satu agensia hayati yang telah dimanfaatkan adalah Trichoderma harzianum. Kemampuan Trichoderma dalam menghasilkan antibiotik dan memarasit patogen di dalam jaringan tanaman inang telah dipelajari secara ekstensif (Harman et al., 2004).

Hasil penelitian Sriwati et al. (2014) menunjukkan bahwa T. harzianum mampu mendominasi ruang hidup dan dapat berkompetisi terhadap patogen. Secara in vitro T.harzianum memiliki kemampuan dalam menghambat pertumbuhan $F$. oxysporum bahkan hifa $T$. harzianum dapat tumbuh di atas hifa $F$. oxysporum. $T$. harzianum mampu memanfaatkan ruang hidup dan nutrisi yang tersedia untuk tetap tumbuh dan bertahan hidup.

Hasil penelitian Sahputra (2017) pengujian pelet yang mengandung berbagai spesies spora Trichoderma dengan masa simpan yang berbeda-beda menunjukkan bahwa $T$. harzianum dengan masa simpan sampai 4 minggu masih dapat bertahan di dalam pelet dan memiliki spora yang tidak berbeda secara signifikan dengan yang disimpan lebih awal.

Penelitian tentang $T$. harzianum dalam menghambat perkembangan penyakit telah banyak dilakukan, akan tetapi untuk penyimpanan dan kemampuannya belum banyak diteliti, oleh sebab itu perlu dilakukan penelitian tentang uji masa simpan pelet $T$. harzianum sebagai agensia pengendalian penyakit layu Fusarium pada bibit tomat dengan beberapa masa simpan pelet.

\section{METODE PENELITIAN}

\section{Tempat dan Waktu Penelitian}

Penelitian ini dilaksanakan di Laboratorium Penyakit Tumbuhan Program Studi Proteksi Tanaman dan Kebun Percobaan Sektor Timur Fakultas Pertanian Universitas Syiah Kuala. Waktu pelaksanaan penelitian pada bulan Mei sampai Agustus 2017.

\section{Alat dan Bahan Penelitian}

Alat yang digunakan pada penelitian yaitu timbangan analitik, gelas ukur, gembor, alat tulis, oven, pisau scalpel, cawan petri, inkubator, mikroskop, Laminar Air Flow Cabinet, autoklaf, pinset, blender, lampu bunsen, jarum ose, gunting, ayakan, meteran, pencetak pelet, dan alat dokumentasi.

Bahan yang digunakan dalam penelitian ini adalah dedak, ampas tahu, molase, Potato Dextrose Agar (PDA), kertas buram, aluminium foil, plastic wrap, tisu, sarung tangan, alkohol 70\%, aquades, spirtus, tanah \& pupuk kandang (1:1), polibag berukuran $200 \mathrm{~g}$, plastik, karet, benih tomat varietas Servo, isolat Fusarium oxysporum dan isolat Trichoderma 
harzianum asal Aceh koleksi dari Laboratorium Penyakit Tumbuhan Program Studi Proteksi Tanaman Fakultas Pertanian Universitas Syiah Kuala.

\section{Rancangan Penelitian}

Rancangan yang digunakan adalah Rancangan Acak Lengkap (RAL) bertaraf tunggal yang terdiri dari 6 perlakuan dengan 3 ulangan, setiap perlakuan terdiri dari 10 unit bibit tanaman tomat. Dengan demikian diperoleh 180 unit tanaman percobaan.

Tabel 1. Susunan Perlakuan Lama Masa Simpan Pelet Trichoderma harzianum

\begin{tabular}{cc}
\hline Perlakuan & Keterangan \\
\hline A & Masa simpan pelet Trichoderma harzianum selama 4 minggu \\
B & Masa simpan pelet Trichoderma harzianum selama 3 minggu \\
C & Masa simpan pelet Trichoderma harzianum selama 2 minggu \\
D & Masa simpan pelet Trichoderma harzianum selama 1 minggu \\
$\mathrm{E}$ & Masa simpan pelet Trichoderma harzianum selama 0 minggu \\
$\mathrm{F}$ & Tanpa pelet Trichoderma harzianum (kontrol) \\
\hline
\end{tabular}

Selanjutnya bila hasil analisis ragam berpengaruh nyata, maka akan dilanjutkan dengan Uji Beda Nyata Terkecil (BNT) pada taraf 5\% (0,05) (Gomez \& Gomez, 1995).

\section{Prosedur Penelitian}

\section{Persiapan Isolat Patogen Fusarium oxysporum}

Isolat cendawan patogen Fusarium oxysporum yang digunakan berasal dari koleksi Laboratorium Penyakit Tumbuhan Program Studi Proteksi Tanaman Fakultas Pertanian Unsyiah. Isolat tersebut diperbanyak dengan menggunakan media beras sebanyak $1 \mathrm{~kg}$, beras dicuci bersih lalu direndam selama 15 menit kemudian ditiriskan hingga kering, selanjutnya dimasukkan ke dalam plastik tahan panas yang berukuran $1 \mathrm{~kg}$. Lalu disterilkan di dalam autoklaf dengan suhu $121^{\circ} \mathrm{C}$ selama 30 menit, dan diinkubasi selama 30 hari (Chamzurni et al., 2010).

\section{Perbanyakan Trichoderma harzianum}

Isolat $T$. harzianum yang digunakan pada penelitian ini berasal dari isolat tanaman pala yang merupakan salah satu koleksi dari Laboratorium Penyakit Tanaman Program Studi Proteksi Tanaman Fakultas Pertanian Unsyiah, selanjutnya isolat tersebut diperbanyak secara aseptik dengan mengambil sebagian kecil menggunakan pisau skalpel lalu dipindahkan pada cawan petri yang berisi media PDA, kemudian diinkubasi selama 5 hari pada suhu ruang $\left(25^{\circ} \mathrm{C}\right)$.

\section{Persiapan dan Pembuatan Pelet Bahan Aktif Trichoderma harzianum}

Formulasi pelet yang digunakan yaitu ampas tahu, dedak, molase, dan aquades. Ampas tahu dijemur hingga kering lalu diblender dan diayak. Selanjutnya adonan dibuat dengan cara mencampurkan dedak $31,0 \mathrm{~g}$, tepung ampas tahu $10,5 \mathrm{~g}$, molase $15 \mathrm{ml}$ dan aquades $42 \mathrm{ml}$ diaduk hingga homogen kemudian dibungkus dengan plastik tahan panas, lalu disterilkan dalam autoklaf dengan suhu $121{ }^{\circ} \mathrm{C}$ selama 30 menit. Kemudian T. harzianum yang telah diinkubasi selama 5 hari pada media PDA dibuatkan suspensi sebanyak $2 \mathrm{ml}$ lalu dimasukkan ke dalam bahan adonan yang sudah disterilkan dengan autoklaf, selanjutnya cendawan diaduk agar tersebar secara merata pada media. Adonan yang sudah disterilkan, diaduk, dan dimasukkan ke dalam alat pencetak lalu dicetak di atas kertas buram. Pembuatan pelet dilakukan di dalam ruang laminar air flow secara aseptik. Pelet tersebut kemudian disimpan di dalam oven selama 48 jam dengan suhu $30{ }^{\circ} \mathrm{C}$ lalu pelet $T$. harzianum dikeluarkan dan dimasukkan ke dalam klip plastik (Soekarno et al., 2014). 


\section{Persiapan Media Tanam}

Tanah yang digunakan sebagai media tanam adalah tanah lapisan atas (top soil) yang diperoleh dari Desa Lambaro Angan Kecamatan Darussalam Aceh Besar, tanah tersebut lalu dikeringanginkan selama 15 hari. Tanah yang telah dikeringanginkan kemudian dibersihkan dari sisa-sisa tanaman dan diayak. Tanah yang telah diayak, kemudian dicampur dengan pupuk kandang dengan perbandingan 1:1. Media tanam tersebut dimasukkan ke dalam polibag berukuran $200 \mathrm{~g}$.

\section{Aplikasi Formulasi Pelet Berbahan Aktif Trichoderma harzianum}

Aplikasi pelet berbahan aktif $T$. harzianum dilakukan satu minggu sebelum inokulasi $F$. oxysporum dengan cara membenamkan pelet dengan dosis $0,5 \mathrm{~g}$ ke dalam media tanam sedalam $3 \mathrm{~cm}$ sesuai dengan perlakuan.

\section{Inokulasi $F$. oxysporum pada Media Tanam}

Fusarium oxysporum diinokulasi satu minggu setelah aplikasi pelet berbahan aktif $T$. harzianum, media beras yang sudah mengandung spora patogen diinokulasi dengan cara membenamkan media beras tersebut ke dalam tanah sedalam $3 \mathrm{~cm}$ sebanyak $1 \mathrm{~g}$ (Susanna et al., 2010). Tanah yang telah diinokulasikan Fusarium ditutup dengan plastik transparan selama 3 hari untuk menjaga kelembaban, kontaminasi, dan merangsang pertumbuhan $F$. oxysporum (Chamzurni et al., 2010).

\section{Persiapan Benih}

Benih tomat yang digunakan dalam penelitian ini, direndam dengan menggunakan air hangat selama 10 menit, benih yang tenggelam ditiriskan untuk digunakan pada persemaian, benih yang terapung tidak digunakan. Tujuan dilakukannya perendaman agar memperoleh benih yang bermutu dan mempercepat proses imbibisi sehingga benih cepat berkecambah di dalam tanah.

\section{Pemeliharaan}

Pemeliharaan tanaman meliputi penyiraman dua kali sehari yaitu pada pagi dan sore hari (tergantung cuaca). Penyiangan gulma dilakukan dengan mencabut gulma yang tumbuh di sekitar tanaman. Pengendalian hama dilakukan secara manual dengan mengambil dan mematikan langsung hama yang ditemukan di sekitar tanaman.

\section{Peubah yang diamati}

Persentase Benih Terserang Sebelum Muncul Ke Permukaan (pre-emergence damping off) $(\%)$

Menurut Muslim et al., (2014) persentase benih terserang sebelum muncul ke permukaan tanah dihitung berdasarkan jumlah benih yang gagal berkecambah. Perhitungan dimulai sejak hari ke-1 sampai ke-10 setelah semai dengan rumus sebagai berikut :

$$
\mathrm{S}=\left[\frac{A-B}{A} \times 100 \%\right]-[100 \%-D]
$$

Keterangan :

$\mathrm{S}=$ persentase pre-emergence damping off

$\mathrm{A}=$ jumlah benih yang disemai

$\mathrm{B}=$ jumlah kecambah muncul ke permukaan tanah

$\mathrm{D}=$ persentase daya kecambah benih 
Persentase Benih Terserang Sesudah Muncul Ke Permukaan (post-emergence damping off) $(\%)$

Persentase post-emergence damping off dihitung, setelah benih muncul di atas permukaan tanah. Perhitungan dimulai sejak muncul kecambah ke permukaan tanah sampai hari ke- 21 setelah semai dengan menggunakan rumus :

$$
\mathrm{K}=\frac{n}{N} \times 100 \%
$$

Keterangan :

$\mathrm{K}=$ persentase bibit terserang post-emergence damping off

$\mathrm{n}=$ jumlah bibit terserang

$\mathrm{N}=$ jumlah benih yang tumbuh

\section{Masa Inkubasi (hari)}

Masa inkubasi diamati sejak inokulasi $F$. oxysporum sampai awal munculnya gejala penyakit layu fusarium yang ditandai dengan gejala awal yaitu menguningnya daun bagian bawah tanaman sehingga mengakibatkan jaringan daun mati (gejala nekrosis) dan kemudian kering. Gejala lebih lanjut akan diikuti dengan layunya bagian batang dan kemudian akan rebah dan mati pada tingkat serangan lebih lanjut.

\section{Persentase Tanaman Layu (\%)}

Pengamatan persentase tanaman layu diamati pada 7, 14, 21, dan 28 hari setelah inokulasi (HSI) dengan menggunakan rumus (Finney, 1971) :

Keterangan :

$$
\mathrm{P}=\frac{a}{b} \times 100 \%
$$

$\mathrm{P}=$ persentase tanaman layu

$\mathrm{a}=$ jumlah tanaman layu

$\mathrm{b}=$ jumlah tanaman yang diamati

\section{Tinggi Tanaman $(\mathrm{cm})$}

Pengamatan tinggi tanaman dilakukan dengan mengukur dari mulai pangkal batang di atas permukaan tanah sampai ke tajuk tertinggi tanaman dengan menggunakan penggaris atau meteran. Pengukuran dilakukan pada 7, 14, 21, 28, dan 35 hari setelah inokulasi (HSI).

\section{HASIL DAN PEMBAHASAN}

\section{Persentase Benih Terserang Sebelum Muncul Ke Permukaan (pre-emergence damping off) $(\%)$}

Hasil rata-rata persentase benih terserang sebelum muncul ke permukaan dapat dilihat pada Lampiran 3. Analisis ragam pada Lampiran 5 menunjukkan bahwa masa simpan pelet $T$. harzianum dalam menghambat penyakit layu Fusarium berbeda tidak nyata terhadap preemergence damping off. Rata-rata benih terserang sebelum muncul ke permukaan dapat dilihat pada Gambar 1. 


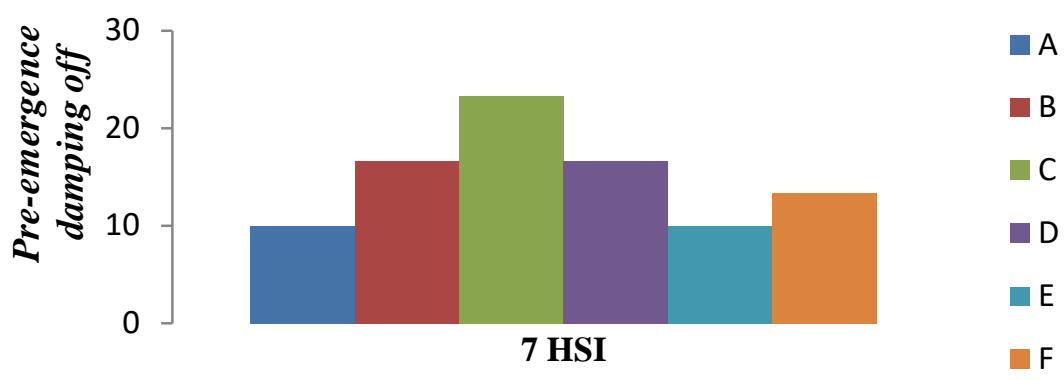

Gambar 1. Rata-rata pre-emergence damping off pada benih tomat akibat pemberian pelet T. harzianum dengan masa simpan yang berbeda pada 7 HSI. Keterangan : $\mathrm{A}=$ masa simpan pelet 4 minggu; $\mathrm{B}=$ masa simpan pelet 3 minggu; $\mathrm{C}=$ masa simpan pelet 2 minggu; $\mathrm{D}=$ masa simpan pelet 1 minggu; $\mathrm{E}=$ masa simpan pelet 0 minggu; $\mathrm{F}=$ tanpa perlakuan (kontrol).

Gambar 1 menunjukkan perlakuan pelet T. harzianum dengan masa simpan 4 minggu (A) efektif dalam menghambat pre-emergence damping-off pada 7 HSI dengan persentase penghambatan tertinggi yaitu $90 \%$. Sedangkan pada perlakuan pelet T. harzianum dengan masa simpan 2 minggu (C) menghasilkan persentase penghambatan terendah yaitu 76,67\% pre-emergence damping-off.

Ketersediaan nutrisi yang baik di dalam bahan pembawa dapat memacu laju pertumbuhan sehingga viabilitas konidia T. harzianum akan terus meningkat. Menurut Pelczar dan Chan (1986), semakin lama waktu penyimpanan pelet dimungkinkan kemampuan perkecambahan konidia (viabilitas) T. harzianum akan tetap atau mengalami penurunan. Hal tersebut karena pertumbuhan mikroorganisme seperti jamur akan memasuki fase statis (stasioner) kemudian fase penurunan atau kematian. Fase statis (stasioner) merupakan fase pertumbuhan mikroorganisme di mana nutrisi dalam media mulai habis dan beberapa sel mati sedangkan sel yang lainnya tumbuh membelah, sehingga jumlah sel yang hidup menjadi tetap. Fase penurunan atau kematian merupakan fase yang menunjukkan banyak sel yang mati karena nutrisi dalam media telah habis dan sel-sel yang mati lebih cepat dibandingkan dengan pertumbuhan pada fase logaritma. Kondisi ini bergantung kepada jenis mikroorganismenya sehingga dimungkinkan semua sel akan mati dalam waktu beberapa hari atau beberapa bulan.

\section{Persentase Benih Terserang Sesudah Muncul Ke Permukaan (post-emergence damping off) $(\%)$}

Hasil rata-rata persentase benih terserang sesudah muncul ke permukaan pada 12 HSI dapat dilihat pada Lampiran 6. Hasil analisis ragam pada Lampiran 8 menunjukkan bahwa masa simpan pelet $T$. harzianum dalam menghambat penyakit layu Fusarium berpengaruh tidak nyata terhadap post-emergence damping off. Rata-rata benih terserang sesudah muncul ke permukaan dapat dilihat pada Gambar 2.

Gambar 2. Rata-rata post-emergence damping off pada benih tomat akibat pemberian pelet $T$. harzianum dengan masa simpan yang berbeda 


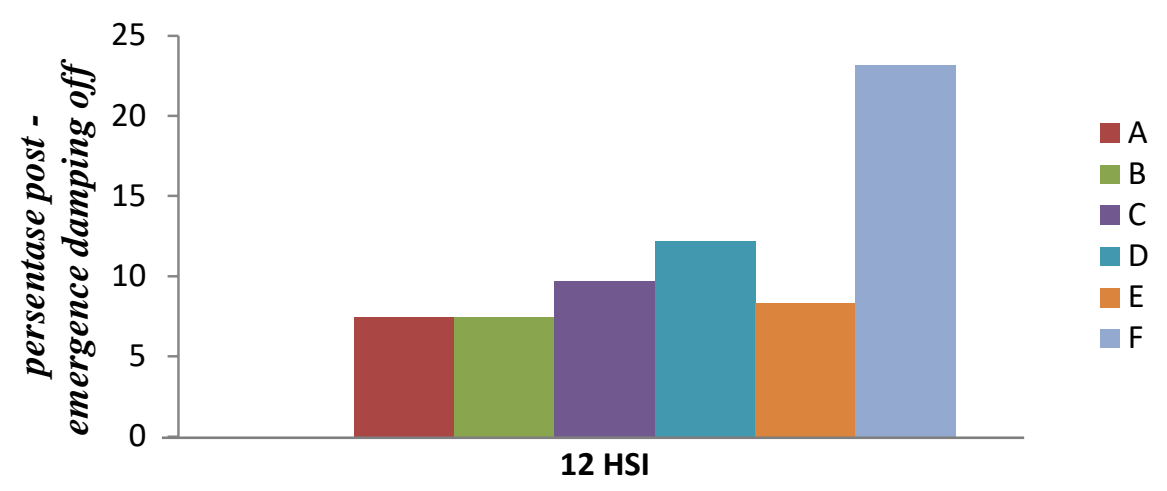

Gambar 2. Rata-rata post-emergence damping off pada benih tomat akibat pemberian pelet T. harzianum dengan masa simpan yang berbeda pada 12 HSI. Keterangan : $\mathrm{A}=$ masa simpan pelet 4 minggu; $\mathrm{B}=$ masa simpan pelet 3 minggu; $C=$ masa simpan pelet 2 minggu; $D=$ masa simpan pelet 1 minggu; $E=$ masa simpan pelet 0 minggu; $\mathrm{F}=$ tanpa perlakuan (kontrol).

Pada Gambar 2 persentase benih yang terserang sesudah muncul ke permukaan berpengaruh tidak nyata dalam menghambat post-emergence damping off pada bibit tomat. Fase post-emergence damping off merupakan fase yang sangat kritis bagi benih maupun kecambah dalam pertumbuhan. Penyakit rebah kecambah sangat berbahaya bagi benih yang berumur kurang dari 3 minggu karena pada fase ini benih dalam keadaan rentan terhadap serangan patogen.

Perlakuan pelet $T$. harzianum masa simpan 4 minggu (A) mampu menghambat postemergence damping off sebesar $92,59 \%$ pada 12 HSI yang diaplikasikan pada bibit tomat. Sedangkan pada tanpa perlakuan pelet T. harzianum kontrol (F) hanya mampu menghambat $76,85 \%$. Hal ini diduga ketersediaan nutrisi yang baik di dalam pelet masa simpan 4 minggu masih mampu berkembang dan beradaptasi pada lingkungan tanah tersebut sehingga dapat memacu laju pertumbuhan viabilitas konidia T. harzianum.

Pada perlakuan kontrol (F) penghambatan persentase post-emergence damping off rendah dibandingkan dengan perlakuan masa simpan pelet $T$. harzianum selama 4 minggu (A). Hal ini dikarenakan pada perlakuan kontrol tidak mengandung pelet $T$. harzianum sehingga patogen yang diinokulasikan akan masuk dengan leluasa dan menginfeksi tanaman, kemudian tanaman layu dan mati.

\section{Masa Inkubasi Penyakit (hari)}

Gejala penyakit layu Fusarium pertama terlihat mulai hari ke tiga setelah inokulasi. Gejala penyakit layu Fusarium diawali dengan menguningnya daun bagian bawah tanaman sehingga menyebabkan jaringan daun mati (gejala nekrosis) dan kemudian kering. Gejala lebih lanjut diikuti layunya tanaman bagian atas, pada serangan tingkat lanjut tanaman akan rebah dan mati. Rata-rata masa inkubasi dapat dilihat pada Gambar 3. 

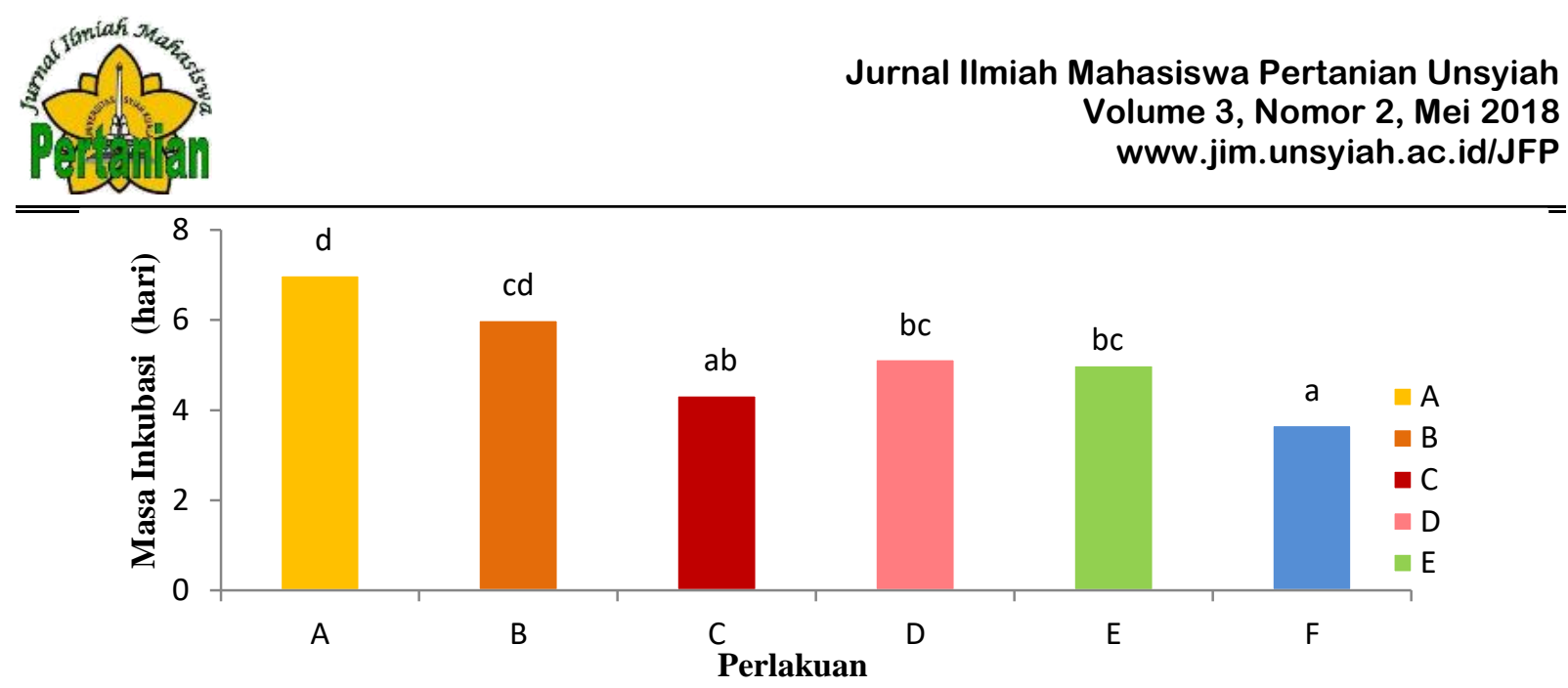

Gambar 3. Rata-rata masa inkubasi akibat masa simpan pelet T. harzianum dalam menghambat penyakit layu Fusarium pada bibit tomat. Keterangan : $\mathrm{A}=$ masa simpan pelet 4 minggu; $\mathrm{B}=$ masa simpan pelet 3 minggu; $C=$ masa simpan pelet 2 minggu; $D=$ masa simpan pelet 1 minggu; $E=$ masa simpan pelet 0 minggu; $\mathrm{F}=$ tanpa perlakuan (kontrol).

Hasil analisis ragam Lampiran 10 menunjukkan bahwa aplikasi masa simpan pelet T.harzianum berpengaruh nyata terhadap masa inkubasi $F$. oxysporum. Pada perlakuan masa simpan pelet $T$. harzianum dengan penyimpanan selama 4 minggu (A) berbeda nyata dengan perlakuan lainnya, namun tidak berbeda nyata dengan pelakuan masa simpan 3 minggu (B), dan pada perlakuan $\mathrm{F}$ (kontrol) berbeda nyata terhadap perlakuan lainnya namun berbeda tidak nyata dengan perlakuan $C$ (masa simpan 2 minggu). Pada perlakuan masa simpan 4 minggu (A) pelet $T$. harzianum mempunyai daya hambat paling tinggi, yaitu 7 hari dan pada perlakuan F (kontrol), mempunyai daya hambat terendah yaitu 4 hari. Masa simpan pelet 4 minggu merupakan masa simpan yang paling efektif dalam memperpanjang masa inkubasi dikarenakan pelet masih efektif menginfeksi patogen. Hal ini sejalan dengan hasil penelitian Marvihayani (2012) yang menyatakan masa simpan pelet $T$. pseudokoningii selama 4 minggu menghasilkan kecepatan koloni lebih tinggi dikarenakan terjadinya perombakan bahan organik dari alang-alang sehingga tersedianya nutrisi bagi perkembangan jamur $T$. pseudokoningii.

Hasil penelitian Latifah et al. (2011) menunjukkan bahwa jamur antagonis T. harzianum isolat jahe yang disiram ke tanaman bawang merah mampu menghambat terjadinya gejala penyakit layu fusarium sebesar $43,85 \%$ yang disebabkan oleh patogen $F$. oxysporum. Hal ini dapat dilihat pada perlakuan masa simpan 4 minggu, menunjukkan hasil penghambatan yang tinggi dari jamur $T$. harzianum terhadap timbulnya gejala penyakit yang disebabkan oleh patogen $F$. oxysporum. Kemampuan menghambat ini disebabkan karena $T$. harzianum memiliki kemampuan berkompetisi dalam memperebutkan ruang, nutrisi, dan oksigen sehingga tumbuh dengan cepat dan menghambat pertumbuhan patogen $F$. oxysporum. Pada perlakuan masa simpan 4 minggu (A) T. harzianum mempunyai daya hambat paling tinggi, sedangkan pada perlakuan F, mempunyai daya hambat terendah. Gejala penyakit paling cepat muncul pada perlakuan $\mathrm{F}$ (kontrol), dengan nilai rata-rata 4 hari setelah inokulasi, hal ini disebabkan karena tidak adanya agensia hayati di dalam tanah, sehingga patogen dengan cepat menyerang bibit tomat. Hal ini sejalan dengan pendapat Mardinus (2006) yang menyatakan bahwa pada perlakuan tanpa agen antagonis akan mempercepat masa inkubasi penyakit layu fusarium. Jamur $F$. oxysporum akan menyerang tanaman melalui akar dan jaringan vaskular lalu berkembang pada jaringan xilem, dapat menghambat proses pergerakan air yang menyebabkan tanaman menjadi layu lalu mati.

\section{Persentase Tanaman Layu (\%)}

Hasil pengamatan persentase tanaman layu pada bibit tomat pada 14, 21,28, dan 35 HSI (Hari Setelah Inokulasi) di sajikan pada Lampiran 13, 16, 19, 22, dan 25. Hasil analisis ragam 
menunjukan bahwa masa simpan pelet $T$. harzianum berbeda tidak nyata terhadap persentase tanaman layu. Rata-rata persentase tanaman layu dapat dilihat pada Gambar 4.

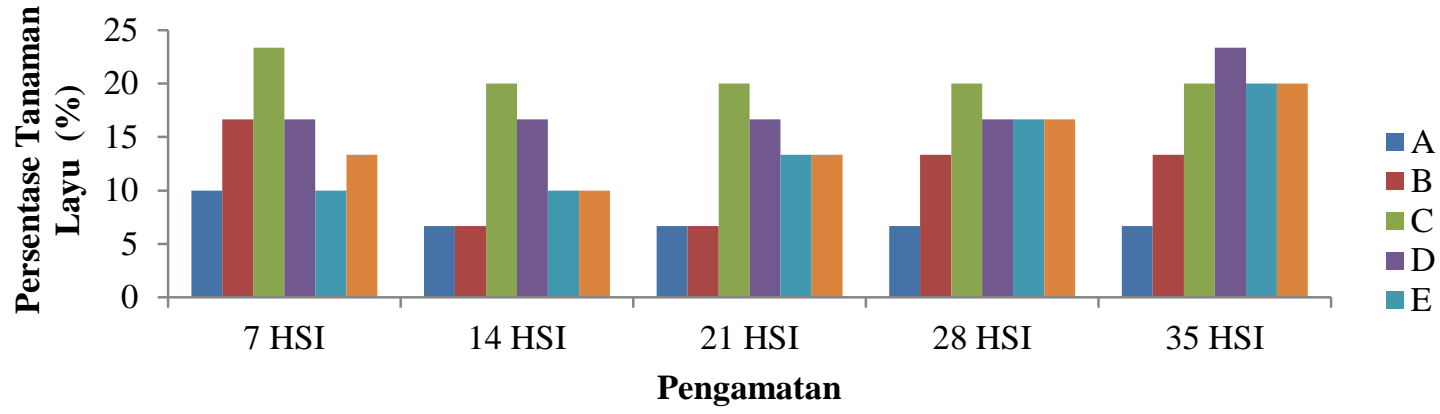

Gambar 4. Rata-rata persentase tanaman layu akibat masa simpan pelet $T$. harzianum dalam menghambat penyakit layu Fusarium pada bibit tomat. Keterangan : $\mathrm{A}=$ masa simpan pelet 4 minggu; $\mathrm{B}=$ masa simpan pelet 3 minggu; $C=$ masa simpan pelet 2 minggu; $D=$ masa simpan pelet 1 minggu; $E=$ masa simpan pelet 0 minggu; $\mathrm{F}=$ tanpa perlakuan (kontrol).

Gambar 4 menunjukkan bahwa rata-rata persentase tanaman layu pada bibit tomat berpengaruh tidak nyata pada setiap perlakuan.

Pada pengamatan 7 HSI perlakuan pelet T. harzianum belum mampu beradaptasi pada lingkungan, sehingga pelet belum mampu menghambat serangan patogen. Hal ini sejalan dengan Soesanto (2008) yang menyatakan bahwa agensia hayati membutuhkan waktu untuk berkembang dan menyesuaikan diri terhadap lingkungan. Pada 14, 21 dan 28 HSI setiap perlakuan menunjukkan penurunan persentase tanaman layu, hal ini diduga bahwa $T$. harzianum telah beradaptasi dan mampu menghambat serangan patogen dengan cara mendegradasi dinding sel pada patogen. Waluyo (2004) menyatakan Trichoderma menyerang patogen dengan cara melilit hifa Fusarium oxysporum secara melingkar dengan mengeluarkan enzim yang mengakibatkan terjadinya kerusakan lapisan kitin pada dinding sel hifa jamur patogen. Pada pengamatan 35 HSI persentase tanaman layu mengalami peningkatan hal ini diduga karena kandungan unsur hara semakin sedikit sehingga T. harzianum tidak mampu berkembang, sehingga patogen mudah menyerang tanaman pada bibit tomat.

\section{Tinggi Tanaman $(\mathbf{c m})$}

Hasil pengamatan terhadap tinggi tanaman pada bibit tomat pada 7, 14, 21,28, dan 35 HSI (Hari Setelah Inokulasi) di sajikan pada Lampiran 26, 28, 30, 32, dan 34. Hasil analisis ragam (Lampiran 27, 29, 31, 33, dan 35) menunjukkan bahwa tinggi tanaman berbeda tidak nyata pada pengamatan masa simpan pelet $T$. harzianum 7, 14, 21 HSI dan berpengaruh nyata pada pengamatan 28 dan 35 HSI. Rata-rata tinggi tanaman dapat dilihat pada Gambar 5.

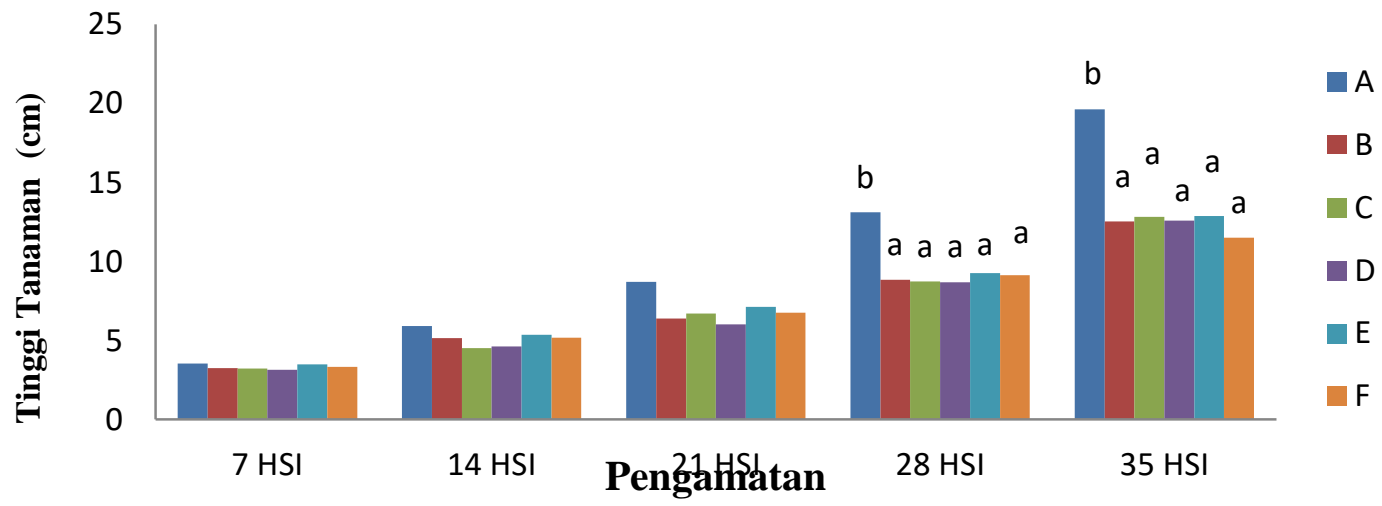

Gambar 5. Rata-rata tinggi tanaman akibat masa simpan pelet $T$. harzianum dalam menghambat penyakit layu Fusarium pada bibit tomat $\left(\mathrm{Uji}_{\mathrm{BNT}} \mathrm{BN}_{0,0}\right)$. Keterangan : $\mathrm{A}=$ masa simpan pelet 4 minggu $; \mathrm{B}=$ masa 
simpan pelet 3 minggu ; $\mathrm{C}=$ masa simpan pelet 2 minggu $; \mathrm{D}=$ masa simpan pelet 1 minggu ; $\mathrm{E}=$ masa simpan pelet 0 minggu $; \mathrm{F}=$ tanpa perlakuan (kontrol).

Tinggi tanaman pada perlakuan masa simpan 4 minggu lebih tinggi dibandingkan dengan perlakuan lainnya, hal ini terjadi diduga karena pelet $T$. harzianum telah beradaptasi dengan bahan organik yang ada di dalam tanah sehingga tersedia untuk pertumbuhan. Peningkatan populasi dan aktivitas antagonis berpengaruh terhadap siklus hidup patogen sehingga pertumbuhan dan perkembangan tanaman semakin baik. Sejalan dengan penelitian Salamiah et al. (2011) menyatakan bahwa viabilitas T. harzianum yang diformulasikan dalam bentuk pelet masih baik pada penyimpanan 4 minggu. Pada media pelet mengandung nutrisi yang dibutuhkan untuk perkembangan $T$. harzianum, nutrisi yang terkandung seperti protein, karbohidrat, lemak serta serat kasar yang baik untuk perkembangan T. harzianum (Soekarno et al., 2014).

Sejalan dengan penelitian Fitriyana (2017) koloni jamur T. harzianum pada formulasi pelet yang disimpan selama 4 minggu masih dapat tumbuh dengan baik saat ditumbuhkan pada media PDA, dikarenakan $T$. harzianum mampu beradaptasi baik dengan lingkungan. Tersedianya karbohidrat, protein, serat, dan vitamin dari dedak dan ampas tahu yang terdapat pada formulasi pelet tersebut. T. harzianum selain digunakan sebagai biokontrol terhadap penyakit layu fusarium, T. harzianum juga memiliki kemampuan sebagai Plant Growth Promoting Fungi yang dapat merangsang pertumbuhan dan meningkatkan produksi tanaman. T. harzianum mampu menghasilkan asam giberelin, benzyl amino purin (BAP) dan hormon auksin berupa IAA (indole- 3 Acetic Acid) yang dapat memacu pertumbuhan tanaman.

Sejalan dengan penelitian Sahputra (2017) bahwa pelet T. harzianum setelah disimpan selama 4 minggu, jumlah spora yang dihasilkan masih tetap stabil dan tidak mengalami penurunan yang signifikan, diduga karena jamur $T$. harzianum cepat beradaptasi dan mampu mendekomposisi bahan-bahan yang ada di pelet dan mampu beradaptasi di lingkungan dengan bantuan enzim selulase yang tinggi.

\section{KESIMPULAN}

Masa simpan pelet $T$. harzianum 4 minggu mampu menghambat perkembangan penyakit layu fusarium serta mampu menunda masa inkubasi sampai 7 HSI, dapat menekan preemergence damping off sampai 90\%, post-emergence damping off 92,59\%, dan meningkatkan tinggi tanaman hingga $19,63 \mathrm{~cm}$ serta meningkatkan jumlah daun rata-rata 7 helai pada 35 HSI di pembibitan tomat.

\section{DAFTAR PUSTAKA}

Badan Pusat Statistika. 2015. Produksi Tomat Provinsi Aceh. http://aceh.bps.go.id/. (online). [03 Maret 2017].

Chamzurni, T., M. A Ulim \& E. Dianur. 2010. Uji ketahanan beberapa varietas tomat terhadap penyakit layu Fusarium (F. oxysporum f.sp lycopersici). J. Agrista 14(2) : 6267

Finney, D. J. 1971. Probit Analysis, Ed. Ke-3. Cambridge University. Cambridge.

Fitriyana, R. 2017. Uji masa simpan dan suhu pengeringan terhadap viabilitas pelet Trichoderma harzianum serta kemampuannya dalam menghambat perkembangan Fusarium oxysporum dan Sclerotium rolfsii (in-vitro). Skripsi. Program Studi Agroteknologi Fakultas Pertanian Universitas Syiah Kuala. Banda Aceh.

Gomez, K. A. \& A. A. Gomez. 1995. Prosedur Statistik Untuk Penelitian Pertanian. Alih Bahasa : E. Syamsuddin \& J. S. Baharsya. Universitas Indonesia. Jakarta. 
Hanindita, N. 2008. Analisis Ekspor Tomat Segar Indonesia. Ringkasan Eksekutif. Program Pascasarjana Manajemen Bisnis Institut Pertanian Bogor. Bogor.

Harman, G. E., C. R. Howell., A. Viterbo., I. Chet., \& M. Lorito. 2004. A Trichoderma spesies-opportunistic, avirulent plant symbionts. Departments of Horticultural Sciences and Plant Pathology. Cornell University. USA. 2(1) : 43-56.

Latifah, A., Kustantinah, \& L. Soesanto. 2011. Pemanfaatan beberapa isolat Trichoderma harzianum sebagai agensia pengendali hayati penyakit layu Fusarium pada bawang merah in Planta. J Eugenia.17(5) : 86-94.

Mardianus. 2006. Jamur Patogenik Tumbuhan. Andalas UNAND. Padang.

Marvihayani, R. 2012. Uji antagonis Trichoderma pseudokoningii rifai dalam formulasi biofungisida yang mengandung alang-alang dengan lama penyimpanan yang berbeda terhadap jamur Ganoderma boninense pat secara in vitro. Skripsi. Universitas Riau. Pekanbaru.

Muslim, A., K. Palimanan., H. Hamidson., A. Salim., \& N. Anwar. 2014. Evaluasi Trichoderma dalam mengendalikan penyakit rebah kecambah tanaman Cabai. J. Fitopatol Indonesia 10(3) : 73-80.

Pelczar, M. J. \& E.C.S. Chan. 1986. Dasar-Dasar Mikrobiologi 1. Penerjemah Ratna Siri Hadioetomo dkk. Universitas Indonesia Press. Jakarta.

Sahputra, I. 2017. Pengaruh masa simpan dan jenis Trichoderma isolat Aceh terhadap pertumbuhan pelet Trichoderma. Skripsi. Program Studi Agroteknologi Fakultas Pertanian Universitas Syiah Kuala. Banda Aceh.

Salamiah, Edwin N. F., \& Asmarabia. 2011. Viabilitas Trichoderma harzianum yang disimpan pada beberapa bahan pembawa dan lama penyimpanan yang berbeda. Fakultas Pertanian Universitas Lambung Mangkurat. Bandar Lampung.

Sharma, P., P. Vignesh Kumar., R. Ramesh., K. Saravanan., S. Deep., M. Sharma., S. Mahesh., \& S. Dinesh. 2011. Biocontrol genes from Trichoderma species : A review. African Journal of Biotechnology 10(86) : 898-907.

Soekarno, B.P., W. Surono., \& Susanti. 2014. Formulasi pelet berbahan aktif Trichoderma sp. dan aplikasinya terhadap penyakit rebah kecambah pada tanaman mentimun. J. Fitopatologi Indonesia 10(5) : 153-159.

Soesanto, L. 2008. Pengantar Pengendalian Hayati Penyakit Tanaman. Grafindo Raja Persada. Jakarta.

Soesanto, L. 2013. Pengendalian Hayati Penyakit Tanaman Edisi Kedua. Rajawali Pers. Jakarta.

Sriwati, R., T, Chamzurni., \& L. Kemalasari. 2014. Kemampuan bertahan hidup Trichoderma harzianum dan Trichoderma virens setelah ditumbuhkan bersama dengan jamur patogen tular tanah secara in vitro. J. Floratek (9) : $14-21$.

Waluyo. 2004. Pengembangan Trichoderma harzianum sebagai bahan pengendalian penyakit tanaman. Makalah pelatihan pemurnian dan penstabilan agens hayati. Dinas Perkebunan Yogyakarta. Yogyakarta.

Wasonowati, C. 2011. Meningkatkan pertumbuhan tanaman tomat (Lycopersicon esculentum Mill). J. Agrovigor 4 (1) : 21-27 